\title{
Debate
}

\section{Prostitutes, workers and kidneys: Brecher on the kidney trade}

\author{
Nicholas Buttle
}

\section{Author's abstract}

Brecher argues that the practices of selling blood and kidneys are akin to the practices of prostitution and wagelabour since they all involve commodification and, by implication, should be subject to legal prohibition. I suggest that these practices need not involve commodification and that they should only be condemned if people are forced into them because of their lack of power. Rather than these practices being prohibited, I suggest that it would be preferable if they were subject to state regulation in order to protect the weak from exploitation.

Brecher's article (1) raises some interesting philosophical and political issues that are worth exploring in more detail because, I think, Brecher does not capture fully the underlying moral issue involved in the kidney trade (together with the practices of prostitution and wage-labour), and, consequently arrives at the wrong political prescriptions.

Brecher argues that if the trade in kidneys and blood is to be condemned then, logically, so should the practices of prostitution and wage-labour. These practices should all be condemned, and those who benefit from them subject to moral censure, because they all involve the commodification of the human being. Although Brecher is not explicit about the political prescription to be drawn from his argument, he would seem to support a legal ban on the selling of kidneys and blood and, presumably, a similar ban on prostitution and wage-labour, or, at least on the physical exploitation of labour (2).

Brecher does not, however, specify precisely what is wrong with the commodification of human beings. Presumably he has in mind some Kantian moral framework whereby it is morally wrong to treat people as though they were a means to an end and not as ends in themselves. Commodification, accordingly, exists when people are treated like things, objects, like any other commodity, a bar of soap, a car, to be bought and sold for the use of others. To treat people as though they are commodities to be used is to deny their

\section{Key words}

Sale of organs; kidneys. freedom and autonomy, their dignity as human beings. But is Brecher right to characterise the sale of blood and kidneys, prostitution, and wage-labour as forms of commodification?

It is not true, surely, that the practices Brecher condemns are necessarily forms of commodification. Individuals may freely choose to engage in these practices so that they may express a person's autonomy rather than his or her commodification. To take one of Brecher's own examples, he illustrates what he has in mind as physically exploitative labour by referring to 'waste disposal workers, train drivers, or ambulance workers' (3). But it is absurd to suggest that people cannot freely choose to engage in these jobs. Out of a commitment to the welfare of others, for instance, I might well choose to be an ambulance worker rather than a philosophy lecturer. Similarly, it is credible to think that individuals may choose to sell their blood, kidneys, or to become prostitutes.

If people can choose to engage in the practices of prostitution, wage-labour, the selling of blood and kidneys, then a legal ban on these activities would constitute an infringement on the freedom and autonomy of individuals. Rather than individuals being respected as ends in themselves, the political prescription that Brecher's analysis seems to support involves a denial of the individual's freedom to engage in those practices that he or she might choose to. Worries might also be raised concerning the extension of state power that the banning of prostitution, etc would involve; the policeman would be on the street corners, in the factories, in the hospitals making sure people were prevented from engaging in illegal acts (4).

Brecher's mistake, I think, is to regard practices such as the selling of kidneys, for instance, as themselves necessarily involving the commodification of human beings. But, I have suggested, this argument is not convincing because it is possible that individuals might freely choose to engage in these practices. It is not the practice of prostitution, wage-labour, or the selling of kidneys, however, that is necessarily wrong but, rather, the circumstances in which these practices are engaged in. The selling of kidneys, for instance, is to be condemned when people are forced into this trade by their circumstances, poverty, or ignorance; and customers are to be censured for taking advantage of 
this situation for their own benefit. Brecher hints at this situation when he refers to slum-dwellers below the poverty line selling their blood, prostitutes selling their bodies because of the social security laws, and Turkish peasants selling their kidneys for $£ 2,000$ (3).

The reality of the situations that Brecher refers to is best characterised, I think, in terms of power rather than commodification. Individuals are forced into practices they would not otherwise choose to be involved in because of a lack of power, usually because of poverty and ignorance, to control their own lives. Customers who buy people's bodies, organs, blood, or labour in these situations should be condemned because they are using their greater power, usually arising from greater wealth, to take advantage of the weak and to exploit them for their own purposes.

What should be condemned, therefore, are not the practices of selling blood, kidneys, bodies, or labour, but the lack of power which forces the weak into these practices, and enables the strong to exploit them. The political prescriptions which follow from this analysis are rather more complex than Brecher's implied legal prohibitions. If people are forced into practices by their lack of power, the remedy for this must lie in addressing this situation. In broad terms this powerlessness of the weak in society requires an extensive redistribution of wealth so that people are not denied the resources which force them, for instance, to sell their kidneys. To be effective, of course, such redistributive measures would have to embrace the Third World since it is there that the greatest dangers of exploitation exist.

In the absence of such large-scale redistribution, however, it is necessary that the state should provide the weak with protection by establishing a legal framework for the regulation, rather than prohibition, of the practices we are concerned with. Regulations do, $\overrightarrow{\vec{F}}$ of course, exist already for working conditions and $\stackrel{?}{?}$ environments whereby workers are afforded some, albeit, no doubt, less than adequate, protection from $\underline{\underline{n}}$ exploitation. Likewise, it would be desirable if $\frac{\bar{c}}{5}$ soliciting and prostitution were to be legalised so that $\stackrel{\mathbb{\Omega}}{\Omega}$ the health and welfare of those who engage in these practices could be given some degree of protection by $\vec{\circ}$ the state, as is already the case in many European countries. Similarly, the selling of blood and kidneys $\vec{\omega}$

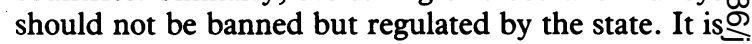
with the protection of legal regulation that the poor and $\bar{\Phi}^{\circ}$ the ignorant might be best prevented from being ${ }_{-}^{-}$ exploited by those able to take advantage of them without, at the same time, the freedom of others being unduly restricted.

Dr Nicholas Buttle is Senior Lecturer in Politics, $\vec{c}$ Department of Economics and Political Science, Bristol Polytechnic.

\section{References}

(1) Brecher B. The kidney trade: or, the customer is always wrong. Fournal of medical ethics 1990; 16: 120-123.

(2) It is not clear why Brecher makes a leap from wage-labour to the physical exploitation of labour. Marx condemned $\frac{\mathrm{Q}}{\mathrm{D}}$ the whole system of wage-labour as a system of $\varrho$ exploitation and slavery and fought for its destruction. $\overrightarrow{\overrightarrow{0}}$ Perhaps the abolition of capitalism is further than Brecher $\exists$ wishes to go.

(3) See reference (1): 122 .

(4) Consenting adults, for instance, would not, to use Robert Nozick's phrase, be allowed to engage in capitalist activities. (continued from page 96)

literature helps us to become sensitised to the anecdotal information and 'soft' data which are essential to the two-way communication of human relationships (3).

\section{$R S$ Downie is Professor of Moral Philosophy at Glasgow University.}

\section{References}

(1) For several years a group of doctors, medical students and others has met at Glasgow University to discuss books, plays and poems related to medicine. For an account of an early stage of this group see Calman K C, Downie R S,
Duthie M, Sweeney B. Literature and medicine: a short course for medical students. Medical education 1988; $22: \%$ 265-269. More recently a conference has been held at Glasgow, and a second conference will be held on Saturday 26 October 1991. Details from the author.

(2) This theme is treated in more detail in Downie $R S$, Calman K C. Healthy respect. London: Faber, 2nd을 impression 1989.

(3) My approach to literature and its bearing on medicine has + been influenced by several writers, but especially Brody H. Stories of sickness. New Haven, London: Yale ${ }_{+}$ University Press, 1987 and Cassell E J. The place of the humanities in medicine. Hastings-on-Hudson: Theत् Hastings Center, 1984. 